\title{
Recenzja monografii Micbała Klimeckiego Sowietyzacja Polski w 1920 roku. Tymczasowy Rewolucyjny Komitet Polski oraz jego instytucje latem i jesienią tegoż roku, Wydawnictwo Naukowe Uniwersytetu Mikotaja Kopernika, Joruń 2016, ss. 339
}

\begin{abstract}
The Review of Michał Klimecki's book Sovietisation of Poland in 1920. The Polish Provisional Revolutionary Committee, as well as its Jnstitutions, in the Summer and Autumn, Wydawnictwo Naukowe Uniwersytetu Mikołaja Kopernika, Toruń 2016, 339 p.

The events of the year 1920 were a unique breakthrough in Polish history, yet now are largely forgotten. The war between the Republic of Poland and the Russian Bolsheviks was, after all, a threat to all of Europe. In Białystok the rulers of red Russia organized their own administration known as the Polish Provisional Revolutionary Committee to govern conquered parts of Polish territory. This body was ultimately going to have transformed itself into the government of a Polish Soviet Republic. This process, as well as the building of the Polish Red Army, is described in the reviewed book. Dr. Klimecki's work also recounts the social background of Polish collaborators of Polish and Jewish origin from soldiers of the Red Army to Polish members of the Communist Party. Fortunately, Polish forces stopped the Bolsheviks at the battle of Warsaw, after which Poland enjoyed twenty years of independence. The reviewed book is an exceptional example of diligent academic work which also describes a now halfforgotten event in the war of 1920.

Keywords: Russian invasion on Poland in 1920, government of Polish Soviet Republic in Białystok, Polish Red Army, Jewish volunteers, felonious ideology of Communism

Slowa kluczowe: rosyjska inwazja na Polskę w 1920 r., rząd „Polskiej Socjalistycznej Republiki Radzieckiej” w Białymstoku, „Polska Armia Czerwona”, żydowscy ochotnicy, zbrodnicza ideologia komunistyczna
\end{abstract}


Wydarzenia roku 1920, jakie rozegrały się na ziemiach polskich, były wielkim przełomem, który jednak odchodzi już w zapomnienie. Wojna z bolszewicką Rosją, która wówczas wybuchła, zagroziła istnieniu nie tylko Rzeczypospolitej, ale i całej Europie. Inwazja Armii Czerwonej była śmiertelnym zagrożeniem nie tylko dla Polski, ale również dla układu sił w Europie po I wojnie światowej'. Oczywiście władze w Moskwie nie tyle liczyły na podbój kontynentu europejskiego wyłącznie siłami swoich wojsk, bo to nie było możliwe, ile na wywołanie ogólnoeuropejskiej rewolty i przejmowanie władzy w poszczególnych krajach przez miejscowych komunistów wszędzie tam, gdzie dotarłaby Armia Czerwona.

Zanim to się stało, władcy Kremla próbowali, jeszcze w czasie działań wojennych, instalować już nową władzę ludową na zajętych przez Armię Czerwoną ziemiach polskich, czyli rząd przyszłej „Polskiej Socjalistycznej Republiki Radzieckiej” w Białymstoku, pod nazwą Tymczasowy Rewolucyjny Komitet Polski, z Julianem Marchlewskim i Feliksem Dzierżyńskim na czele.

Proces ten opisał znany historyk Michał Klimecki w omawianej monografii Sowietyzacja Polski w 1920 roku. Praca dzieli się siedem rozdziałów; zawiera także bibliografię, wykaz skrótów, streszczenie (w językach angielskim i rosyjskim) oraz indeks nazwisk.

Recenzowana monografia została napisana zgodnie z układem chronologicznym, ale treścią wybiega poza okres roku 1920 zakreślony w tytule, ponieważ Autor przedstawił w rozdziale pierwszym postawę polskich komunistów w kraju - wobec samej koncepcji „radzieckiego państwa polskiego” - redagowaną już od grudnia 1918 r. (do końca lipca 1920 r.). Chcąc trafić do szerokich kręgów polskiego społeczeństwa, komuniści wydawali własny organ prasowy, „Przełom” (w podtytule: „Tygodnik Komunistyczny”, o nakładzie ok. 8 tys. egz.), w którym usiłowali zjednać do swojej marksistowskiej ideologii możliwie najszersze kręgi, głosząc powszechną równość, z zapewnieniem w przyszłości powszechnego dobrobytu, gdy tylko przejmą władzę.

Komuniści byli właściwie jedyną grupą polityczną, która pozostawała permanentnie w negatywnej postawie wobec sukcesów wojsk polskich, uważając, że jest to wymierzone w bolszewicką Rosję. Stąd każdą militarną operację Armii Czerwonej uznawali za całkowicie uzasadnioną, jako odpowiedź na polskie działania wojskowe, traktowane jako agresję na pierwsze „państwo robotników i chłopów”. Ale wszelkie mityngi, jakie urządzali pod koszarami polskiego wojska, nie spotykały się z szerszym poparciem i rodziły jedynie wrogość (s. 31).

$\mathrm{W}$ rozdziale drugim omówiono stosunek polskich komunistów do kwestii istnienia niepodległej Rzeczypospolitej, ale tych przebywających na terenie bolszewickiej Rosji, którzy dzielili się wyraźnie na dwie grupy; pierwsza, najbardziej krzykliwa i pełna serwilizmu wobec rosyjskich bolszewików, stała na stanowisku całkowitego włączenia odrodzonego państwa polskiego do formalnie federacyjnej Rosji radzieckiej, jako kolejnej republiki (tutaj przewodzili głównie komuniści pochodzenia żydowskiego;

\footnotetext{
1 „Jeszcze kilka dni zwycięskiej ofensywy - mawiał Włodzimierz Lenin, przywódca rosyjskich komunistów - a nie tylko Warszawa byłaby zdobyta, [...] lecz rozbity byłby pokój wersalski”, W. Lenin, O Polsce i polskim ruchu robotniczym, Warszawa 1954, s. 500. Zob. też J. Smaga, Narodziny i upadek imperium ZSRR 1917-1991, Kraków 1992; Z. Brzeziński, Wielkie bankructwo. Narodziny i śmierć komunizmu wXX wieku, Paryż 1990.
} 
Julian Leszczyński-Leński i najmocniej - Józef Unszlicht). Julian Marchlewski i Feliks Dzierżyński natomiast reprezentowali grupę, która opowiadała się za niewielką, ale jednak, niezależnością, w ramach „federacyjnej”, komunistycznej Rosji.

Inaczej rozkładały się również pewne akcenty co do przychodzenia „z pomocą” polskim komunistom w ustaleniu władzy ludowej w Warszawie przez Armię Czerwoną. Pierwsza grupa była zdecydowanie za rosyjską inwazją, druga skłaniała się do wspomagania polskich komunistów materiałowo, aby sami przejęli władzę w państwie polskim i potem zwrócili się z uniżoną prośbą do nowych władców Kremla o przyłączenie do bolszewickiej Rosji (Autor przypomniał, że tę drugą opcję przyjęli komuniści niemieccy, którzy sami zamierzali, na drodze przewrotu, przejąć władzę w Berlinie). Jedno jest pewne - członkowie obydwóch tych grup, pomimo zasadniczo niewielkich różnic, nie ośmielali się w najmniejszym stopniu sprzeciwiać decyzjom rządu Lenina. „Godzili się - jak pisze Autor (s. 98) - z rolą organu wykonawczego, którego kompetencje określał KC RKP [...] i pozostawali w jego dyspozycji zarówno jako Biuro, jak i indywidualnie". Nie odgrywając zresztą u boku bolszewickich mocodawców takiej roli, jaką odegrać pragnęli. Dla Lenina największe znaczenie miało zwycięstwo i przejęcie władzy przez niemieckich komunistów w Berlinie, ponieważ w połączeniu rewolucji rosyjskiej z niemiecką widział on szansę na podbój całej Europy (zagarnięcie Polski miało dużo mniejsze znaczenie i było tylko fragmentem tego planu).

Szczegółową analizę projektów bolszewickich przywódców i naczelnego dowództwa Armii Czerwonej wobec kwestii polskiej (od grudnia 1918 r. do lipca 1920 r.) Autor zawarł w rozdziale trzecim. Wynika z niej, że władze radzieckie nie traktowały zbyt poważnie białostockiego komitetu. Dowódcy Armii Czerwonej starali się hamować agresywne zapędy ujawniających się lokalnych komisarzy nowej władzy (rekrutujących się najczęściej z miejscowych parobków i biedoty miejskiej), dyszących klasową nienawiścią nie tylko do wykształconych środowisk ziemiańskich, ale nawet do nieco zamożniejszych chłopów.

Dowództwo rosyjskiego Frontu Zachodniego wielokrotnie wydawało rozkazy zabraniające żołnierzom Armii Czerwonej oraz miejscowym komunistycznym aparatczykom, brutalnego traktowania polskiej ludności cywilnej, co jednak w niczym nie zmniejszało rosyjskiego bestialstwa. W dniu 21 lipca 1920 r. dowódca Frontu Zachodniego Michaił Tuchaczewski, w siedzibie sztabu w Smoleńsku przypomniał, że „wojna z Polską toczy się przeciw burżujom i ziemiaństwu, a ubogim chłopom i robotnikom ma przynieść uwolnienie od wszelkiego ucisku". W końcu lipca, w swoim armijnym rozkazie wydanym w Grodnie, żądał: „Żadnej litości dla pańskiej Polski” (s. 140).

Na słabą pozycję komitetu białostockiego w oczach władz radzieckich wskazuje wyraźnie brak przekazywania informacji z Kremla, nawet o toczących się rokowaniach rozejmowych z przedstawicielami państw zachodnich, głównie Wielkiej Brytanii. Wszystko wskazywało na to, że w wypadku szybkiego zawarcia rozejmu cała misja komitetu uległaby szybkiemu zakończeniu.

W dalszej części monografii Autor zawarł szczegółowy opis struktur zarówno komitetu białostockiego, jak i organizowanego na galicyjskich terenach zajętych przez Armię Czerwoną Galrewkomu (Galicyjskiego Rewolucyjnego Komitetu), który miał być tymczasowym rządem przyszłej Galicyjskiej Socjalistycznej Republiki Radzieckiej (przetrwała zaledwie od 8 lipca do 21 września 1920 r.). Ustanowiono tam nową admi- 
nistrację, milicję ludową, nowy system sprawiedliwości, edukacji oraz zaczęto tworzyć galicyjską Armię Czerwoną. Wprowadzono rosyjską walutę oraz jako języki urzędowe: ukraiński, polski i... żydowski (jidysz) ${ }^{2}$.

Wkraczająca na ziemie polskie Armia Czerwona natychmiast po zajęciu kolejnej miejscowości wyznaczała lokalne komitety wojskowo-rewolucyjne (rewkomy), obsadzane głównie własnymi działaczami bolszewickimi, nieposiadającymi większego doświadczenia i mówiącymi wyłącznie po rosyjsku. Ich zadaniem było m.in. dobieranie do tych komitetów przedstawicieli lokalnego proletariatu. Ponieważ godzili się na to nieliczni, więc rekrutowano zupełnie przypadkowych osobników, deklarujących służalcze posłuszeństwo nowym władcom, przeważnie spośród miejscowych, niepiśmiennych parobków (na Podlasiu w większości prawosławnych), a nawet ze środowisk przestępczych. Łącznie powstało 65 takich komitetów, które mieniły się organami lokalnej administracji, a w rzeczywistości uprawiały zwykły bandytyzm³ ${ }^{3}$.

Autor podkreślił, że w organach nowej władzy ludowej największą rolę (po działaczach mówiących wyłącznie po rosyjsku) odgrywali członkowie społeczności żydowskiej, ponieważ stosunkowo trudno było znaleźć ochotników do współpracy z bolszewickim najeźdźcą spośród wykształconych Polaków. Poza tym działacze żydowscy przeważnie znali dobrze język rosyjski, co ułatwiało porozumiewanie się z rosyjskimi towarzyszami. Nawet polscy komuniści (żydowskiego pochodzenia) działający w organach bolszewickiej Rosji, jak Feliks Kon i Karol Radek (wlaśc. Sobelsohn), przyznawali, że np. w Siedlcach rosyjscy organizatorzy rewkomów musieli oprzeć się na ochotnikach żydowskich, bo tylko tacy wykazywali zapał do współpracy z Armią Czerwoną. Niektórzy wstępowali nawet w jej szeregi i walczyli z oddziałami Wojska Polskiego, będąc formalnie obywatelami Polski (s. 256).

W kilku miastach Mazowsza i Podlasia młodzież żydowska wstępowała na ochotnika do Armii Czerwonej (w Tyszowicach, Hrubieszowie czy Włodawie otwarto biura werbunkowe). Liczące 500 osób żydowskie oddziały ochotnicze powstały w Siedlcach, Białymstoku i Białej Podlaskiej. Oddział, liczący 120 członków, uprawiał dywersję na tyłach polskiej 4. Armii. W Hrubieszowie ludność żydowska strzelała do wycofujących się oddziałów polskich. W Siedlcach demonstracyjnie przemalowywała napisy na szyldach swoich sklepów w języku polskim na napisy w języku rosyjskim. W miastach powiatu makowskiego i pułtuskiego na powitanie bolszewików wyszli z chlebem i solą żydowscy kupcy, pragnąc pozyskać przychylność rosyjskich najeźdźców ${ }^{4}$. Autor

\footnotetext{
${ }^{2}$ Rozpętano również wyjątkowo zaciekłą, antyreligijną kampanię propagandową; na jednym z wieców komunistyczny agitator krzyczał: „Chrystusa nie było, Chrystus teraz się urodził, teraz my sami Chrystusami jesteśmy. [...] Do kościołów będzie się bydło zapędzać, a nie ludzie chodzić tam będą”, M. Klimecki, Galicyjska Socjalistyczna Republika Rad. Okupacja Małopolski (Galicji) Wschodniej przez Armię Czerwona w 1920 roku, Torun 2006, s. 168.

3 J. Goclon, 1920 „Ojczyzna w niebezpieczeństwie”, Wrocław 2000, s. 92-94.

${ }^{4}$ J. Goclon, W obronie Europy. Wojna z bolszewicka Rosja w 1920 roku, Komorów 2015, wyd. IV, zmien. i poszerz., s. 210-241; J. Szczepański, Wojna 1920 roku na Mazowszu i Podlasiu, Warszawa 1995, s. 226-231; M. Nałęcz Dobrowolski, Żydzi-bolszewicy a Polska, Warszawa 1920, s. 13; T. Mścisławski, Wojsko polskie a Żydzi, Warszawa 1923, s. 18. Por. S. Wysocki, Żydzi w dziejach Polski, Warszawa 1995, s. 94; A. Albert, Najnowsza historia Polski, Warszawa 1983, cz. 1, s. 53; W. Najdus, Lewica polska w Kraju Rad 1918-1920, Warszawa 1971, s. 302 i nast.; R. Korsch, Żydowskie ugrupowania wywrotowe w Polsce, Warszawa 1925, s. 31; Z.M. Musialik, Wojna polsko-bolszewicka 1919-1920 a Żydzi, Częstochowa 1995, s. 71.
} 
zasadnie podsumował, że „kolaboracja osób żydowskiego pochodzenia była wyraźnie widoczna, zwłaszcza w miastach i miasteczkach, w których stanowili oni bardzo liczną grupę mieszkańców" (s. 256).

Co nie znaczy, że „komitety rewolucyjne” nie miały swoich zwolenników wśród polskiej ludności, ale $\mathrm{z}$,sympatią do rewkomów odnosiły się również (poza ludnością żydowską) najbiedniejsze warstwy wsi, małorolni chłopi i robotnicy rolni” (s. 256). Komitet białostocki mieli poprzeć także robotnicy stolicy Podlasia; natomiast członków Polskiej Partii Socjalistycznej rosyjscy komuniści uważali za „szpiegów i sługusów burżuazji”" (s. 256).

Ważną kwestią, którą Autor omówił, był także proces tworzenia „Polskiej Armii Czerwonej”, walczącej przeciwko Polsce, u boku armii rosyjskiej, do której ochotniczo wstępowali nie tylko żydowscy ochotnicy, ale również osoby polskiego pochodzenia (najczęściej rekrutujące się z marginesu społecznego, często kryminalnego) - nienawidzące „pańskiej” Polski. Omówiony został także los tej niewielkiej formacji po zawarciu rozejmu z polskim dowództwem, w wyniku przegranej bitwy nad Niemnem.

Ciekawą informację stanowi przytoczenie wypowiedzi Lenina, który we wrześniu 1920 r. przyznał, że „radziecka Rosja poniosła klęskę w wojnie z Polską” i który planował wznowienie działań wojennych na wiosnę 1921 r., ale ostatecznie w gronie władców Kremla przeważył pogląd, że wojnę z Polską należy „wznowić, ale po wybuchu rewolucji w Niemczech" (s. 266)

Autor podkreślił również, że rosyjscy i polscy komuniści zrozumieli, że „rewolucję można wywołać i wygrać jedynie dzięki wewnętrznym napięciom społecznym, a wojskowa interwencja zewnętrzna bardziej zaszkodzi, niż pomoże wystąpieniu przeciwko państwu" (s. 275). Bardzo trafna jest uwaga, że z doświadczeń przegranej wojny z Polską przywódcy bolszewickiej Rosji wynieśli przekonanie, że po inwazji na inne kraje „należy możliwie szybko i brutalnie zlikwidować wszystkie przejawy samodzielności na zajętych terenach i dopiero po tym instalować podległe Moskwie nowe organy władzy i administracji niższych szczebli”, co zastosowali w końcu II wojny światowej, zajmując wschodnią Europę (s. 310).

Zdziwienie wywołują jednak pewne sformułowania, jakby nieco z minionej epoki, np. że „do bolesnej porażki [w wojnie z Polską] przyznawał się również, co dostrzegali uważni czytelnicy jego zebranych prac, wódz wielkiej październikowej rewolucji [...] Lenin" (s. 307). Z całym naciskiem należy przypomnieć, że historiografia dawno odeszła już od takich pojęć i dzisiaj jest rzeczą powszechnie znaną, że bolszewicki przewrót, przeprowadzony jesienią 1917 r. w Piotrogrodzie (dzisiaj Sankt Petersburg), był zwykłym zamachem stanu i nie tylko przez wiele dni, ale nawet tygodni, nieznanym w dalszych rejonach Rosji, a nie żadną „wielką socjalistyczną rewolucją październikową”, jak to wydarzenie określano do końca istnienia PRL, we wszystkich podręcznikach szkol-

\footnotetext{
5 Niezwykle „,barwne” wytłumaczenie rosyjskiej klęski podał Jarosław Jurkiewicz, pisząc: „Ani pomoc Ententy, ani wysiłki Watykanu nie uratowałyby reakcji polskiej, gdyby nie zdrada Trockiego i Tuchaczewskiego, wskutek której ofensywa Czerwonej Armii została powstrzymana. Lecz interwenci nie mieli już możliwości dalszego kontynuowania wojny i dlatego doszło do zawarcia traktatu pokojowego w Rydze", J. Jurkiewicz, Nuncjatura Achillesa Ratti w Polsce, Warszawa 1955, s. 60; M. Klimecki, Sowietyzacja Polski..., s. $266,267$.
} 
nych ${ }^{6}$. Poza tym Autor nie przytoczył niemal wcale, do jakich zbrodni dochodziło na terenach zajętych przez Armię Czerwoną, dokonywanych na polskiej ludności cywilnej, opisując jedynie aspekty ustrojowe i ideologiczne, bez ukazywania, co ta komunistyczna doktryna, z jej rosyjską, bolszewicką odmianą, niosła innym narodom (powszechną grabież, demoralizację całych narodów - i nieznane wówczas na taką skalę - ludobójstwo!).

Pierwsza próba podboju Polski w 1920 r. zakończyła się zupełną klęską. Wówczas bolszewicka Rosja, przy udziale polskich komunistów - uchodzących przez całe dwudziestolecie za symbol zaprzaństwa i narodowej zdrady - nie zdołała narzucić zbrodniczej ideologii, prowadzącej do gospodarczej ruiny i zniewalania całych narodów ${ }^{7}$.

Najbardziej obłąkanej ideologii w całych dziejach świata, którą komuniści tak przerażająco skutecznie zmieniali ludzką psychikę (poprzez terror, skrajnie zakłamaną propagandę i sianie klasowej nienawiści) dokonując całkowitych przewartościowań dotychczasowych zasad współżycia ludzkości ${ }^{8}$. Przypomnijmy pamiętne słowa Winstona Churchilla, który w kwietniu 1919 r. przerażająco trafnie stwierdził: „Ze wszystkich tyranii w historii bolszewicka jest najgorsza, najbardziej niszczycielska, najbardziej poniżająca"".

M. Klimecki jednak wyraźnie uchylił się od wartościowania komunistycznej ideologii, z której hasłami rosyjscy komuniści dokonywali w 1920 r. inwazji na Polskę.

Niezależnie od tych przemilczeń omawiana monografia jest cenną edycją; wnosi wiele nowego o niemal zapomnianym epizodzie funkcjonowania rządu „Polskiej Socjalistycznej Republiki Rad” w 1920 r., zarówno dla środowiska naukowego, jak i dla szerszego czytelnika, i dobrze się stało, że ukazała się na rynku wydawniczym.

${ }^{6}$ Zdziwienie budzi także podanie odbioru postaci Feliksa Dzierżyńskiego w radzieckiej historiografii, bez ustosunkowania się Autora do tej „świetlanej opinii”, iż „Przewodniczący [w rzeczywistości wiceprzewodniczący] Tymczasowego Komitetu Feliks Dzierżyński w radzieckiej przestrzeni historycznej pozostawał niezłomnym, skromnym przywódcą Czeki [Wszechrosyjskiej Nadzwyczajnej Komisji do Walki z Kontrrewolucją i Sabotażem, której oprawcy w stosowaniu tortur wobec swoich często urojonych przeciwników stanęli na najwyższych szczeblach zwyrodnienia], bliskim współpracownikiem Lenina i Stalina, wybitnym internacjonalistą, cokolwiek to ostatnie mogło oznaczać", M. Klimecki, Sowietyzacja Polski..., s. 307-308; J. Goclon, 1920 „Ojczyzna w niebezpieczeństwie”, s. 7-14.

${ }^{7}$ W szczytowym okresie swojej krzykliwej propagandy polscy komuniści II Rzeczypospolitej liczyli zaledwie ok. 4 tys. członków, a w czasie II wojny światowej ok. 6 tys., M.J. Chodakiewicz, Po zagładzie. Stosunki polsko-żydowskie 1944-1947, Warszawa 2008, s. 28.

${ }^{8}$ Zob. W. Roszkowski, Przeksztatcenia spoleczne i gospodarcze w Polsce w latach 1944-1970, [w:] Polski wiek XX, t. 3, red. K. Persak, P. Machcewicz, Warszawa 2010, s. 97.

${ }^{9}$ P. Johnson, Historia świata (od roku 1917), Londyn 1989, s. 82. 